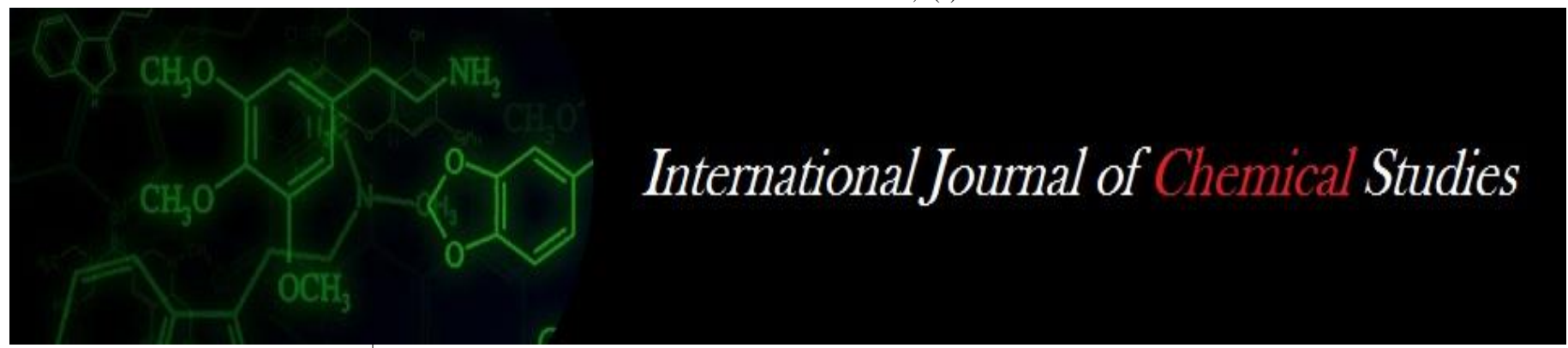

P-ISSN: 2349-8528

E-ISSN: 2321-4902

www.chemijournal.com

IJCS 2020; 8(4): 2635-2637

(C) 2020 IJCS

Received: 10-05-2020

Accepted: 12-06-2020

Koushal Kishor Bijarnia

M.Sc. Student, Department of

Agronomy, College of

Agriculture, Agriculture

University, Jodhpur, Rajasthan, India

\section{UN Shukla}

Assistant Professor, Department

of Agronomy, College of

Agriculture, AU, Jodhpur,

Rajasthan, India

Vijay Laxmi Yadav

Ph.D. Student, Rajasthan

Agricultural Research Institute,

Durgapura, SKNAU, Jobner,

Rajasthan, India

\section{Effect of stress mitigating chemicals and sulphur on plant population and grain yield of mungbean [Vigna radiata (L.) Wilczek]}

\author{
Koushal Kishor Bijarnia, UN Shukla and Vijay Laxmi Yadav
}

DOI: https://doi.org/10.22271/chemi.2020.v8.i4ae.10032

\begin{abstract}
The field experiment was conducted during the kharif season 2019 to investigate the effect of stress mitigating chemicals and sulphur on plant population and grain yield of mungbean [Vigna radiata (L.) Wilczek]. The experiment laid out in Factorial Randomized Block Design with sixteen treatment combinations comprised of four stress mitigating chemicals and four sulphur levels with three replications. The result shows that initial plant population of mungbean was found unaffected by all the treatments. Application of thiourea @ 500 ppm (FI) enhanced significantly final plant population and grain yield of mungbean and significant increment in both traits were also observed in the treatment of sulphur@ $@ 40 \mathrm{~kg} / \mathrm{ha}$. The interaction effect of stress mitigating chemicals and sulphur levels had a significant effect on grain yield of mungbean.
\end{abstract}

Keywords: Mungbean, plant population, grain yield, stress mitigating chemicals, sulphur

\section{Introduction}

Pulses contribute 24.79 million hectares area with production of 22.0 million tonnes and productivity of $765 \mathrm{~kg} / \mathrm{ha}$ in the country. Pulses production is very low and become challenging problem against the requirement of increasing population of our country. The availability of pulses is very negligible at present as against required $85 \mathrm{~g} \mathrm{day}^{-1}$ capita $^{-1}$ for balanced diet. Mungbean occupies third rank after chickpea and pigeon pea. It is grown on 4.25 million hectares area in India with production of 2.41 million tonnes and average productivity of $567 \mathrm{~kg} / \mathrm{ha}$ (Anonymous, 2019) ${ }^{[2]}$. In India, Rajasthan occupied first position with 26 per cent of the total mungbean production of India, which produces 1.24 million tonnes from 1.92 million hectares and in Rajasthan with an average productivity of $650 \mathrm{~kg} / \mathrm{ha}$ (Anonymous, 2019) ${ }^{[2]}$. Mungbean is mostly grown in arid and semi-arid districts of Rajasthan including Nagaur, Jodhpur, Jaipur, Ajmer, Jalore, Srigangnagar, Tonk, Churu, Barmer and jhunjhunu.

It is mostly grown in the area of salinity in farms that are in arid and semi-arid areas in all the regions of the world are a major problem. The dry spell frequently observed during kharif season due to erratic nature of rainfall particularly in Rajasthan and mungbean being a short duration crop is most affected. It is reported to be more susceptible to water deficit than many other grain legumes. Therefore, stress mitigating chemicals like salicylic acid and thiourea are play important role in escaping drought in mungbean (Ali and Mahmoud, 2013) ${ }^{[1]}$. Sulphur deficiencies have been reported from over 70 countries worldwide including India. Deficiency of sulphur in Indian soils is on increase due to intensification of agriculture with high yielding verities and multiple cropping coupled with the use of high analysis sulphur free fertilizers along with the restricted or no use of organic manures have accrued in depletion of the soil sulphur reserve.

Thiourea is a sulphydryl compound (Jocelyn, 1972) ${ }^{[6]}$, it contains one $-\mathrm{SH}$ group $(42.1 \% \mathrm{~S})$ besides containing nitrogen $(36.8 \%)$ in the form of $\mathrm{NH}_{2}$. Use of thiourea, recognized as plant growth regulator (Sahu and Solanki, 1991) and is known to bring marked biological activity in plants. Its beneficial effect appears to be due to delayed senescence of both vegetative and reproductive organs as thiourea has cytokinin like activity, particularly delaying senescence (Halmann, 1980) ${ }^{[5]}$. Foliar spray of thiourea has been reported not only to improve growth and
Corresponding Author: Koushal Kishor Bijarnia M.Sc. Student, Department of Agronomy, College of Agriculture, Agriculture University, Jodhpur, Rajasthan, India 
development of plants, but also the dry matter partitioning for increased grain yield (Arora, 2004) ${ }^{[3]}$. It promotes growth in cytokinin requiring callus tissues in absence of kinetin in various crops.

Salicylic acid (SA) is a naturally occurring plant hormone acting as an important signaling molecule which adds to tolerance against abiotic stresses. It plays a vital role in plant growth, ion uptake and transport. Salicylic acid is involved in endogenous signaling to trigger plant defense against pathogens. This positive effect of SA could be attributed to an increased $\mathrm{CO}_{2}$ assimilation, photosynthetic rate and increased mineral uptake by the stressed plant under SA treatment. Plants respond to environmental stresses by synthesis of signaling molecules. These signaling molecules activate a range of signal transduction pathways, some of which relieve the plant to overcome stress (Simaei et al., 2012) ${ }^{[10]}$.

Sulphur is recognized as fourth major nutrient after nitrogen, phosphorus and potassium. On an average, the amount of sulphur content in the earth crust is ranged about 0.06 to 0.10 per cent. Pulses are particularly responsive to sulphur containing fertilizers, and that elementary sulphur or sulphates increases the percentage of nitrogen as well as yield on such deficient soils (Khorgami and Farnia, 2006) ${ }^{[7]}$. Its deficiency has been reported from several states of India and importance of sulphur application of increasing crop yield and quality is being increasingly recognized. It is essential for the growth and development of plants, besides it stimulates seed formation (Singh et. al. 2017) ${ }^{[11]}$.

Application of these stress mitigating chemicals in conjunction with fertilizer doses might be provide a best management practice in order to understand the proven technology. Since, under such situation, the crop response to fertilizer application varies due to deficit moisture or uncertain weather conditions.

\section{Materials and Methods}

A field experiment was conducted during kharif season of 2019 at Instructional Farm, College of Agriculture, Jodhpur (Rajasthan).Which is situated at a distance of about $10 \mathrm{~km}$ from Jodhpur railway station. Geographically, it is located between $26^{\circ} 15^{\prime} \mathrm{N}$ to $26^{\circ} 45^{\prime}$ North latitude and $73^{\circ} 00^{\prime} \mathrm{E}$ to latitude $73^{\circ} 29^{\prime}$ East longitude at an altitude of 231 meter above mean sea level (MSL). This region falls under agroclimatic zone Ia (Arid Western Plains Zone) of Rajasthan. Soil of the experimental field was loamy sand in texture with alkaline in reaction $(\mathrm{pH} 8.2)$, low in organic carbon $(0.13 \%)$ and available nitrogen (174 kg/ha), medium in available phosphorus $(22.2 \mathrm{~kg} / \mathrm{ha})$ and potassium $(325 \mathrm{~kg} / \mathrm{ha})$.
Experiment was laid out in factorial randomized block design with sixteen treatment combinations comprised of four stress mitigating chemicals (control, Salicylic acid @ 75 ppm first spray at flower initiation stage of mungbean and second spray was applied at seven days after first spray, Salicylic acid @ $75 \mathrm{ppm}+2 \%$ urea at flower initiation stage of mungbean, and thiourea @ 500 ppm at flower initiation stage) and four sulphur level viz. (control, $20 \mathrm{~kg}$ sulphur/ha, $30 \mathrm{~kg}$ sulphur/ha and $40 \mathrm{~kg}$ sulphur/ha). The mungbean variety GM-6 was sown using seed rate $15 \mathrm{~kg} / \mathrm{ha}$ with a row spacing of $30 \mathrm{~cm}$ at the depth of $4-5 \mathrm{~cm}$. Uniform dose of nitrogen and phosphorus $15 \mathrm{~kg} \mathrm{~N} / \mathrm{ha}, 40 \mathrm{~kg} \mathrm{P}_{2} \mathrm{O}_{5} / \mathrm{ha}$ was applied to all the plots by adjusting the nitrogen supplied by DAP and remaining through urea at the time of sowing. Whereas, sulphur was applied through elemental sulphur as per treatment. Foliar spray of thiourea was done @ 500 ppm, Salicylic acid @ 75 ppm and Salicylic acid @ 75 ppm + 2\% urea flowering stages as per treatments.

\section{Result and Discussion \\ Effect of stress mitigating chemicals}

Data shows that initial plant population in all the treatments of mungbean was not affected. Therefore, all the treatments were found significant effect on final plant population (lakh/ha) and grain yield $(\mathrm{kg} / \mathrm{ha})$ of mungbean in comparison to control (Table 1). Application of thiourea @ 500 ppm (FI) was found superiority in final plant population (3.10 lakh/ha) and grain yield $(1055 \mathrm{~kg} / \mathrm{ha})$ of mungbean and it was found at par with Salicylic acid@75 ppm+2\% urea (FI). Thiourea application might have helped in improvement in metabolic processes of plants and better growth and development owing to greater absorption of nutrients from rhizosphere. These findings are close to conformity with Bamaniya (2009) ${ }^{[4]}$.

Effect of Sulphur

\section{Effect of sulphur}

All the sulphur treatments were significantly increased plant population (lakh/ha) and grain yield $(\mathrm{kg} / \mathrm{ha})$ of mungbean over control (Table 1). The maximum plant population (3.07 lakh/ha) and grain yield (1062 kg/ha) of mungbean was recorded under sulphur @ $40 \mathrm{~kg} / \mathrm{ha}$, which was found at par with its lower doses treatment (Sulphur @ $30 \mathrm{~kg} / \mathrm{ha}$ ). This might be due to the sulphur application improved over all nutritional environment of the rhizosphere as well as plant system, which helpful for profuse vegetative and root growth and activate higher absorption of nutrients from the soil. The results are in close agreement with the findings Singh and Yadav, 2000 and; Rani and Vedparkash, $2017^{[12,8] .}$

Table 1: Plant population and grain yield of mungbean as influenced by stress mitigating chemicals and sulphur

\begin{tabular}{|c|c|c|c|}
\hline \multirow{2}{*}{ Treatments } & \multicolumn{2}{|c|}{ Plant population (lakh/ha) } & \multirow{2}{*}{ Grain yield $(\mathrm{kg} / \mathrm{ha})$} \\
\hline & Initial & Final & \\
\hline \multicolumn{4}{|l|}{ A. Stress mitigating chemicals } \\
\hline $\mathrm{C}_{0}$ : Control & 3.15 & 2.98 & 760 \\
\hline $\mathrm{C}_{1}$ : Salicylic acid @ 75 ppm (FI)+7 DAFS & 3.16 & 3.04 & 902 \\
\hline $\mathrm{C}_{2}:$ Salicylic acid @ $75 \mathrm{ppm}+2 \%$ urea $(\mathrm{FI})$ & 3.18 & 3.07 & 1034 \\
\hline $\mathrm{C}_{3}:$ Thiourea @ 500 ppm $(\mathrm{FI})$ & 3.21 & 3.10 & 1055 \\
\hline SEm \pm & 0.26 & 0.02 & 17.15 \\
\hline $\mathrm{CD}(\mathrm{P}=0.05)$ & NS & 0.05 & 59.54 \\
\hline \multicolumn{4}{|l|}{ B. Sulphur } \\
\hline $\mathrm{S}_{0}$ : Control & 3.15 & 3.00 & 726 \\
\hline $\mathrm{S}_{1}: 20 \mathrm{~kg} / \mathrm{ha}$ & 3.17 & 3.05 & 916 \\
\hline $\mathrm{S}_{2}: 30 \mathrm{~kg} / \mathrm{ha}$ & 3.18 & 3.06 & 1047 \\
\hline $\mathrm{S}_{3}: 40 \mathrm{~kg} / \mathrm{ha}$ & 3.20 & 3.07 & 1062 \\
\hline $\mathrm{SEm} \pm$ & 0.26 & 0.02 & 17.15 \\
\hline $\mathrm{CD}(\mathrm{P}=0.05)$ & NS & 0.05 & 59.54 \\
\hline
\end{tabular}




\begin{tabular}{|c|c|c|c|}
\hline Interaction $(\mathrm{C} \times \mathrm{S})$ & & & \\
\hline $\mathrm{SEm} \pm$ & 0.53 & 0.32 & 34.31 \\
\hline $\mathrm{CD}(\mathrm{P}=0.05)$ & $\mathrm{NS}$ & $\mathrm{NS}$ & 99.09 \\
\hline
\end{tabular}

FI-Flower initiation, DAFS-Days after first spray

\section{Interaction effect}

Interaction between stress mitigating chemicals and sulphur was found significant with respect to grain yield of mungbean (Table 2). The treatment combination, thiourea@500 ppm $(\mathrm{FI})+$ sulphur @ $40 \mathrm{~kg} / \mathrm{ha}\left(\mathrm{C}_{3} \mathrm{~S}_{3}\right)$ recorded significantly higher grain yield of mungbean and it was found statistically at par with treatment combination, Salicylic acid @ 75 ppm + $2 \%$ urea $(\mathrm{FI})+$ Sulphur @ $30 \mathrm{~kg} / \mathrm{ha}\left(\mathrm{C}_{2} \mathrm{~S}_{2}\right)$. The results indicated that synergistic effect of stress mitigating chemicals and sulphur on grain yield of mungbean.

Table 2: Interaction effects of stress mitigating chemicals and sulphur on grain yield of mungbean

\begin{tabular}{|c|c|c|c|c|c|}
\hline \multirow{2}{*}{$\mathbf{C} \times \mathbf{S}$} & \multicolumn{4}{|c|}{ Grain yield (kg/ha) } & \multirow[b]{2}{*}{ Mean } \\
\hline & $\mathrm{C}_{0}$ & $\mathbf{C}_{1}$ & $\mathbf{C}_{2}$ & $\mathrm{C}_{3}$ & \\
\hline $\mathrm{S}_{0}$ & 604 & 634 & 832 & 835 & 726 \\
\hline $\mathrm{S}_{1}$ & 746 & 910 & 998 & 1011 & 916 \\
\hline $\mathrm{S}_{2}$ & 837 & 1072 & 1166 & 1112 & 1047 \\
\hline $\mathrm{S}_{3}$ & 853 & 992 & 1140 & 1262 & 1062 \\
\hline Mean & 760 & 902 & 1034 & 1055 & \\
\hline \multicolumn{6}{|c|}{$\mathrm{SEm} \pm 34.31$} \\
\hline
\end{tabular}

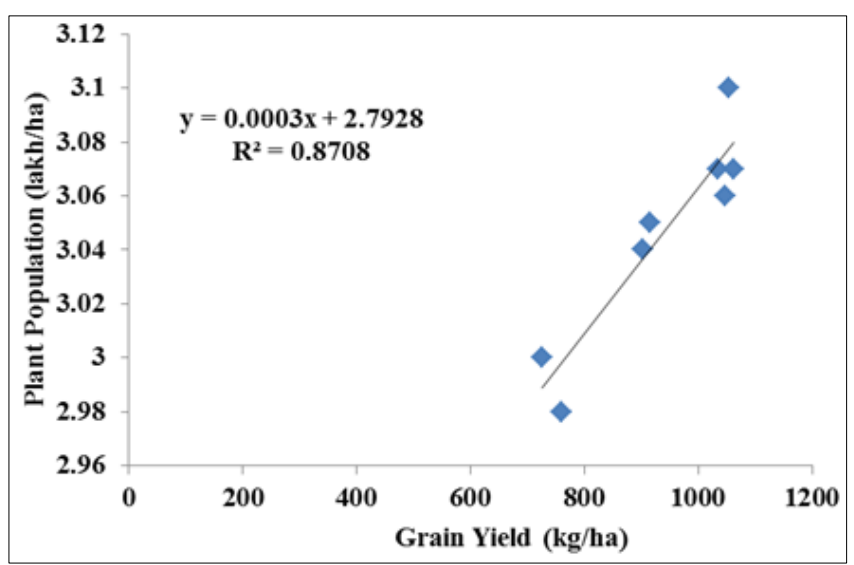

Fig 1: Regression analysis between plant population (lakh/ha) and grain yield $(\mathrm{kg} / \mathrm{ha})$ of mungbean

\section{Regression analysis}

Plant population (lakh/ha) and grain yield (kg/ha) of mungbean were positively correlated with correlation coefficient of $\mathrm{R}^{2}=0.8708$. This was further supported by the regression analysis, which revealed that every 100 plants will increases $2 \mathrm{~kg}$ grain yield of mungbean.

\section{Conclusion}

The experimental results concluded that foliar application application of thiourea@ 500 ppm along with sulphur @ 40 $\mathrm{kg} / \mathrm{ha}$ recorded significantly higher final plant population and grain yield of mungbean, which was found at par with treatment combination salicylic acid @ 75 ppm $+2 \%$ urea (FI) and fertilized with Sulphur @ 30 kg/ha.

\section{References}

1. Ali EA, Mahmoud AM. Effect of foliar spray by different salicylic acid and zinc concentrations on seed yield and yield components of mungbean in sandy soil. Asian Journal of Crop Science. 2013; 5(1):33-40.
2. Anonymous. Crop-wise fourth advance estimates of area, production and yield of various principal crops during. Commisionerate of Agriculture, Govt. of Rajasthan, Jaipur, 2019.

3. Arora D. Effect of thiourea and zinc on growth, yield and quality of barley (Hordeum vulgare L.) Ph.D. Thesis, Rajasthan Agricultural University, Bikaner, 2004.

4. Bamaniya PK. Effect of thiourea and zinc on productivity of mungbean [Vigna radiate (L.) Wilczek]. M.Sc. (Ag.). Thesis, Rajasthan Agricultural University, Bikaner, 2009.

5. Halmann M. Synthetic plant growth regulators. Advances in Agronomy. 1980; 43:47-105.

6. Jocelyn PC. Biochemistry of -SH group. The occurrence, Chemical properties, Metabolism and Biological Function of Thiols and Di-sulphides. Academic Press, London, 1972, 44.

7. Khorgami A, Farnia A. Effect of phosphorus and zinc fertilization on yield and yield components of chick pea cultivars. African Crop Science Conference Proceedings. 2006; 9:205-208.

8. Rani M, Vedparkash. Effect of Phosphorus, Sulphur and PSB on Growth Attributes and Yield of Mungbean (Vigna radiata L. Wilczek). Journal of AgriSearch. 2017; 4(3):198-201.

9. Sahu MP, Solanki NS, Dashora LN. Effect of thiourea and ascorbic acid on growth and yield of maize (Zea mays L.). Journal of Agronomy and Crop Science. 1993; 171:65-90.

10. Simaei M, Khavari-Nejad RA, Bernard F. Exogenous application of salicylic acid and nitric oxide on the ionic contents and enzymatic activities in NaCl-stressed soybean plants. American Journal of Plant Sciences. 2012; 3:1495-1503.

11. Singh P, Yadav KK, Meena FS, Singh B, Singh R. Effect of phosphorus and sulphur on yield attributes, yield and nutrient uptake of mungbean (Vigna radiata L.) in Central Plain Zone of Punjab. Plant Archives. 2017; 17(2):1756-1760.

12. Singh U, Yadav DS. Economics of summer green gram (Phaseolus radiates L.) cultivation as influenced by sulphur and zinc levels. Legume Research. 2000; 23(1):67-68. 